\title{
New, north-easternmost locality for Bembidion monticola Sturm, 1825 (Coleoptera: Carabidae) in Europe: relict of ancient distribution or a result of range expansion?
}

\author{
Yakov N. Kovalenko \& Dmitry Telnov
}

Kovalenko, Ya. N. \& Telnov, D. 2018: New, north-easternmost locality for Bembidion monticola Sturm, 1825 (Coleoptera: Carabidae) in Europe: relict of ancient distribution or a result of range expansion? — Entomol. Fennica 29: 119124.

A new record of a subpopulation of Bembidion monticola Sturm, 1825 from Arkhangelsk region (Northern Europe, Russia) is discussed. The locality of this record is remote, about $700 \mathrm{~km}$ to the east from the northernmost previously known locality of this species. Ecology and distribution of B. monticola in northern Europe are reviewed, as well as possible ways of its spread further to northeast are hypothesised.

Ya. N. Kovalenko, Severtsov Institute of Ecology and Evolution, Russian Academy of Sciences, 33 Leninskiy prosp., 119071, Moscow, Russia. E-mail: sinodendron.rus@gmail.com

D. Telnov, Dārza iela 10, Stopiņu novads, LV-2130, Dzidringas, Latvia. E-mail: anthicus@gmail.com

Received 7 September 2017, accepted 26 January 2018

\section{Introduction}

Bembidion monticola Sturm, 1825 is a European boreo-montane ground beetle species distributed in several mountain systems of Europe and the Caucasus, as well as on the Northern European plains (Müller-Motzfeld 2004). In the latter region, it is rare, with only a few modern records. For example, in Finland only a single locality of extant population is currently known for this species (Venn \& Kankare 2005). In the Latvian fauna, $B$. monticola is regarded as a "very rare species with few known localities" (Barševskis et al. 2008). In the region considered (Fig. 1), the species is also known from Lithuania (Tamutis et al. 2011), Estonia (Haberman 1968) and Denmark (Hansen 1996), as well as from the Karelian Isthmus (Kryzhanovskij 2010), being rare and sporadic throughout.
Previously published subpopulations of $B$. monticola monticola in Northern Europe lie far to the south-west of the Pinezhsky Nature reserve, and are generally close to the Baltic Sea basin (Lindroth 1985, 1988, Venn \& Kankare 2005) (Fig. 1).

The new locality for B. monticola monticola in Arkhangelsk region is currently the north-easternmost in the known range of the species: it is more than $700 \mathrm{~km}$ east of the previous easternmost locality in the Karelian Isthmus (Kryzhanovskij 2010) and approximately $300 \mathrm{~km}$ north of the previous northernmost locality in Finland (Venn \& Kankare 2005).

Bembidion monticola monticola Sturm, 1825 is a European endemic distributed sporadically across Central, Western, Southern and partly Northern Europe and has a large total distribution area (Marggi et al. 2003). The second subspecies, 


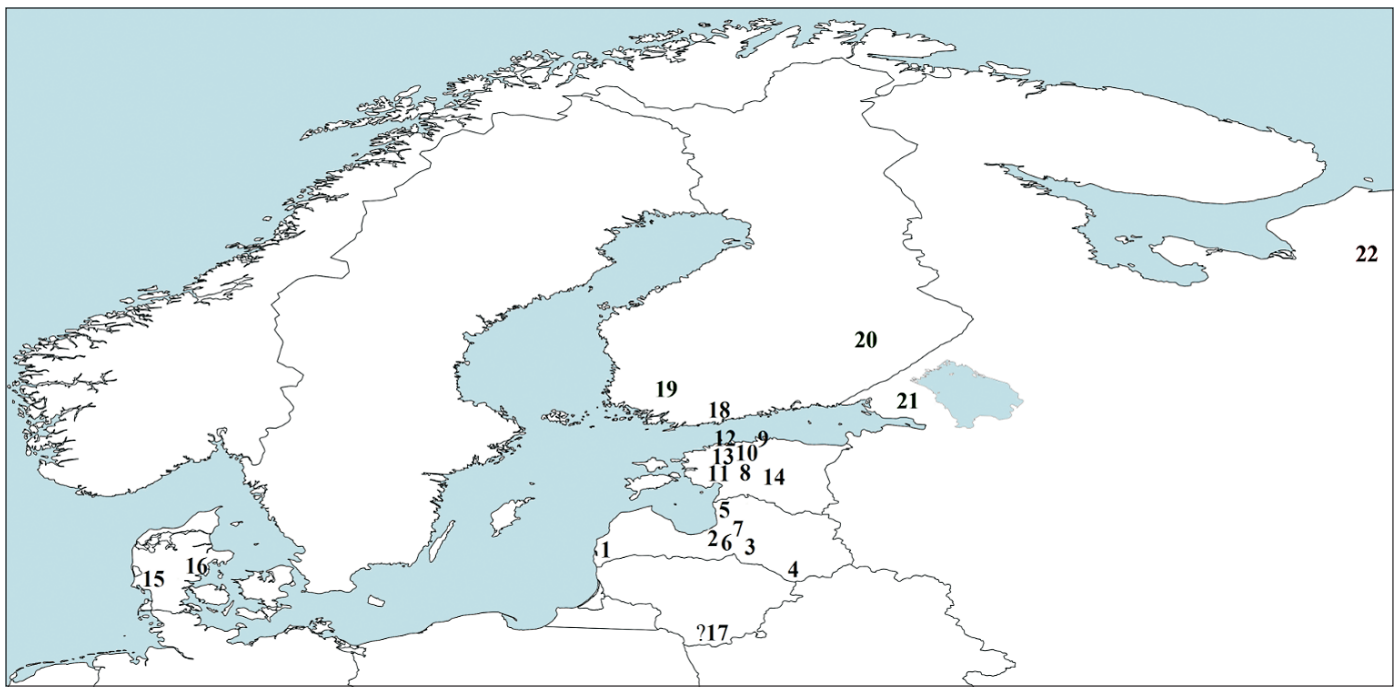

Fig. 1. Distribution of Bembidion monticola monticola in Northern Europe, Denmark and the Baltics. Numbers refer to localities in the region. LATVIA: 1 - Paplaka (Lackschewitz \& Mikutowicz 1939); 2 - Dārzingi (Šmits 1968; Savich 1998; D. Telnov, unpubl.); 3 - Pljavingas (Stiprais 1958); 4 - Naujene (Barševskis 1993); 5 - Vīkgi (Barševskis et al. 2008); 6 - Ogre (D. Telnov, unpubl.); 7 - Kārli, Gauja National park (Ch. Fägerström, unpubl.); ESTONIA: 8 - Kolu, 9 - Võsu, 10 - Aegviidu, 11 - Velise (Haberman 1968); 12 - Mustjõe, 13 - Kiisa, 14 - Lalsi (I. Süda, unpubl.); DENMARK: 15 - East Jutland, 16 - West Jutland (Hansen 1996; Venn \& Kankare 2003); LITHUANIA: 17 - Zervynos (Miländer 1984, record needs further confirmation (see text); FINLAND: 18 - Espoo (Venn \& Kankare 2003); 19 - Pusula, 20 - Juuka (Lindroth 1985); RUSSIA: 21 - the Karelian Isthmus (O. L. Kryzhanovskij, unpubl.); 22 - Pinezhsky Nature reserve (Sotka River), new subpopulation of the present study.

B. monticola ponticum Korge, 1964, is known from Caucasus and Transcaucasia (Armenia, Georgia) as well as from E Turkey (western Lesser Caucasus) (Kryzhanovskij et al. 1995). The third subspecies, B. monticola makolskii Netolitzky, 1929 is known from Poland (Marggi et al. 2003).

Bembidion monticola monticola usually inhabits riversides of mostly montane rivers and streams. Only in certain regions (e.g. Baltic States, Germany, Northern Belarus, Denmark, Finland, Karelian Isthmus and Northern Poland) this species is also reported from lowland areas (Netolitzky 1942-1943, Müller-Motzfeld 2004, Solodovnikov 2008a, b, 2011).

Habitat preferences of this species vary. In mountainous areas it inhabits stony riverbanks, but in forested regions in Northern Belarus (Belarusian Poozerie region) it has been occasionally found under bark of deciduous trees standing in the water of rivers and large streams under shady conditions (Solodovnikov 2008a, b, 2011 and pers. comm.). One specimen of $B$. monticola has been found on sandy riverbank in Lithuania (Miländer et al. 1984). The Lithuanian specimen of B. monticola monticola published by Miländer $e t$ al. (1984) and later cited by numerous authors (e.g. Tamutis et al. 2011) is a female (V. Tamutis, pers. comm.).

External morphological characters of this species are insufficient for certain identification. More material, specifically males, is required to confirm the identification and thus the presence of this species in the Lithuanian fauna $(\mathrm{K} . \mathrm{V}$. Makarov, pers. comm.). In Latvia, B. monticola monticola is mostly associated with dolomite riverbanks (usually these river sections have strong flow), where it is observed under pieces of dolomite close to the water (Savich 1998, Ch. Fägerström unpubl., Telnov unpubl.). In Estonia, several localities are known for B. monticola monticola (Haberman 1968, I. Süda unpubl.).

The aim of our present work is to introduce the occurrence of $B$. monticola significantly north-east of the previously known range, as well as attempt to explain this phenomenon. 


\section{Specifics of the new finding of B. monticola}

Nine adults of Bembidion monticola monticola Sturm, 1825 (Fig. 2) were collected 13.VIII.2010 by the first author on a rockslide on the right (southern) bank of Sotka River under stones (most likely dolomite) at the shoreline (Fig. 3) in the Pinezhsky Nature reserve (geographical coordinates of the locality: $64^{\circ} 38^{\prime} 31.0^{\prime \prime} \mathrm{N}, 42^{\circ} 53^{\prime}$ 31.8'E) together with B. petrosum Gebler, 1833. All specimens are mounted on card mounts and labelled. The material was examined using a Zeiss Stemi 2000 C stereomicroscope; macrophotography of specimens was performed using Canon EOS-40D camera with Canon MP-E 65 mm lens.

One of the leading Russian carabidologists, Kirill V. Makarov, confirmed the identification of this species. One specimen is deposited in the collection of the Moscow State Pedagogical University while the other 8 specimens are in the private collection of the first author.

\section{Discussion}

Bembidion monticola monticola is considered a glacial relict in Northern Europe, having survived in one or more probably montane refugia unaffected by glaciation, and spreading from there across Northern Europe after the ice cap receded (Lindroth 1992). In this context, it is worth mentioning that all known Finnish populations are associated with old, ruined water-mills, where conditions optimal for montane (lithophilous) species are formed by the stone fragments from the ruins (Venn \& Kankare 2005), which may attest to the migratory origin of these populations. Incidentally, the population found in Pinezhsky Nature reserve is associated with the canyon-like part of Sotka River valley, characterised by vertical gypsum walls up to $70 \mathrm{~m}$ high, with numerous rockslides on both banks, which give it a resemblance to montane regions and provide habitat that is in many ways similar to truly montane (Fig. 3).

According to Edemski (1931), dolomite formations and dolomitized limestone occur in the Kuloy River basin, of which the Sotka River

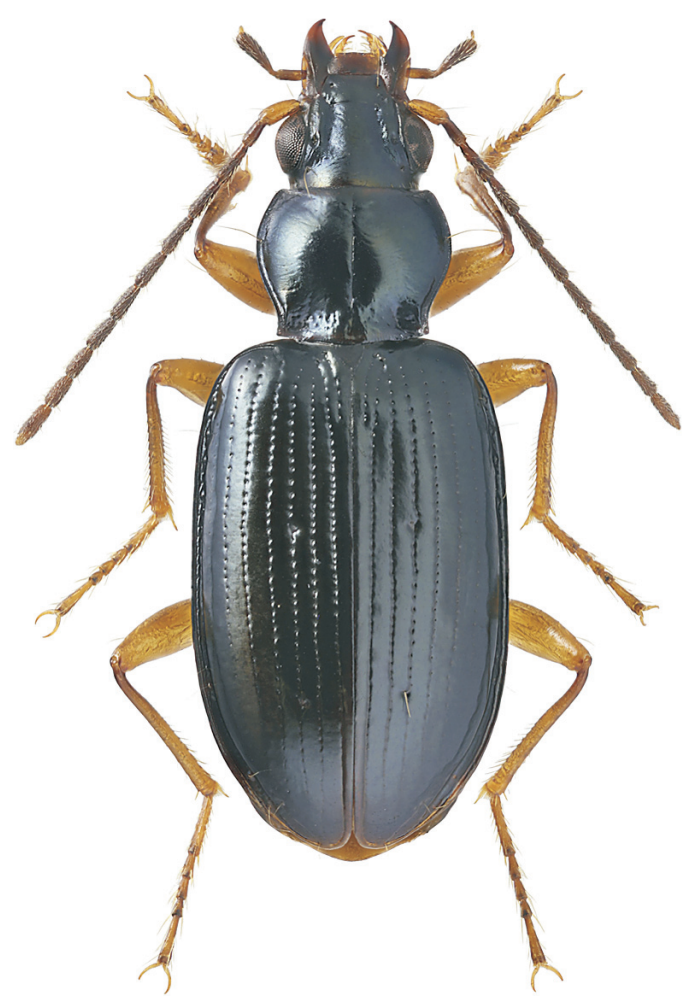

Fig. 2. Bembidion monticola monticola Sturm, 1825 specimen from Pinezhsky Nature reserve. Photograph by Kirill V. Makarov.

(where the new observations were made) is a tributary. According to an earlier publication by the same author on the geology and mineralogy of the Sotka River in particular (Edemski 1926), the sheer walls of canyon-like part of its bed are composed largely of dolomites. This can be indirect confirmation of ecological connection of $B$. monticola monticola with dolomite formations (and, possibly, also gypsum) in Northern Europe.

The distribution pattern of this species in Northern Europe (Fig. 1) clearly demonstrates that B. monticola monticola occurs only at relatively short distances from the Baltic Sea. This is probably explained by the buffer role of the Atlantic Ocean and the Baltic Sea as part of it, specifically by the heat capacity of water masses ensuring higher temperatures than further inland. This phenomenon is a characteristic feature of the marine climate of the temperate latitudes of the Earth, characteristic of north-western Europe (Khromov \& Petrosyants 2006). 


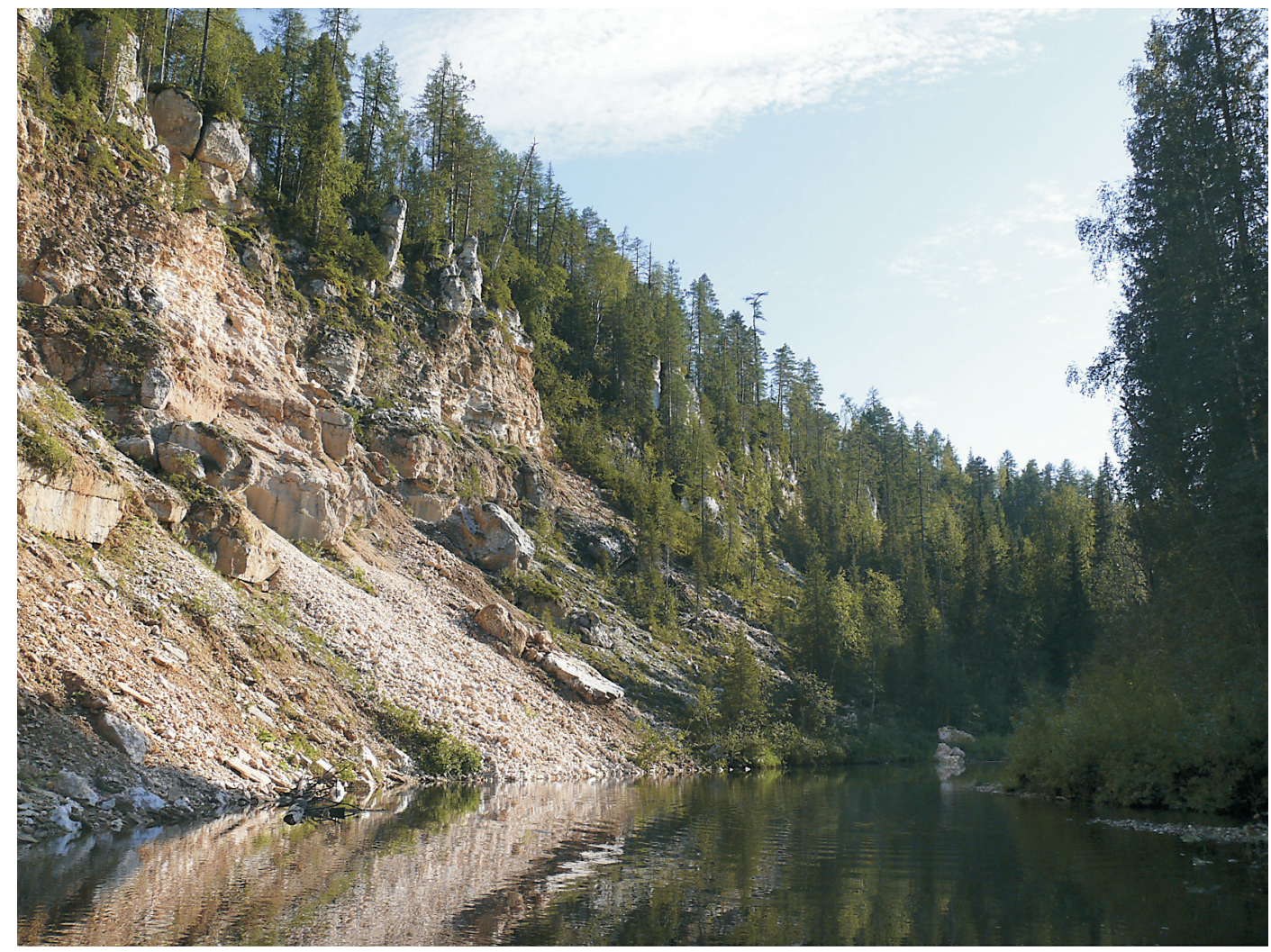

Fig. 3. Rockslide at Sotka riverbank where Bembidion monticola monticola was sampled. Photograph by Aleksey V. Gornov.

At the same time, Pineshzsky Nature reserve, as the entire territory of the Middle Pinezhye, belongs to the Atlantic-Arctic climatic region of the temperate zone and has completely different temperature and climatic patterns than the surrounding areas. This may be related to the finding of the northernmost population of $B$. monticola specifically there. The territory of the Pinezhsky Nature reserve and its environs are known as the development area of very complex and diverse superficial karst phenomena, the northernmost in the East European plain (Shalybkov et al. 1988).

One of the consequences of the massive karst development in this area is the presence of numerous underground streams and small rivers, as well as springs coming up to the surface (called "talets" in the local dialect). Surface lakes and rivers originating from these karst springs do not freeze even during the most severe frosts (for example, Lake Beloe near Pinega village and the river of the same name starting from this lake) (Edemski 1926), even if the January mean tem- perature (the coldest month in Pinezhye) is -16.6 ${ }^{\circ} \mathrm{C}$ and an absolute registered temperature minimum is $-48.6^{\circ} \mathrm{C}$ (Shalybkov et al. 1988).

The river Sotka, particularly interesting in the present context for its temperature and hydrological aspects and for its $B$. monticola monticola subpopulation, receives a large amount of water from these "talets" over the whole length of its canyon-like bed. The water of the "talets" originates from karst caves and has a constant yearround temperature. The consequence of this yearround feeding of the River Sotka with "geothermal" karst waters (in quotation marks, because the water temperature of these springs does not exceed +2 to $+4{ }^{\circ} \mathrm{C}$ ) is that in many places the Sotka does not freeze completely in winter, even during frosts of -30 to $-40{ }^{\circ} \mathrm{C}$ (Shalybkov et al. 1988). In our opinion, there is a possible connection between these "geothermal" peculiarities of the Sotka River and the existence of the northernmost $B$. monticola monticola subpopulation, situated so far from the Atlantic. Possibly, the pres- 
ence of permanently unfrozen areas is critical for species of the "water-land" ecotone (inhabiting, like $B$. monticola monticola in our case, riversides in proximity to water). In contrast, those riversides not fed by "thermal" karst waters in winter time offer much less suitable niches for existence of riparian beetle species, especially during the strong frosts that are so common in the study area.

Of all Coleoptera groups in Pinezhsky Nature reserve, only ground beetles (Carabidae) are considered sufficiently studied (Filippov \& Mokhnatkin 2008). Consistently with the situation of $B$. monticola monticola, these authors mentioned three species typical of more southern regions, namely Calosoma investigator (Illiger, 1798), Lebia cruxminor (Linnaeus, 1758) and L. chlorocephala (J. J. Hoffmann, 1803). Possibly, their occurrence at the northern limit of their distribution area (both Lebia species) or at a relatively long distance from their main distribution area (C. investigator) can also be explained by peculiar temperature conditions in Pinezhsky Nature reserve due to the presence of the "geothermal" karst phenomena discussed above.

It is not excluded that prior to the last glaciation $B$. monticola monticola was much more widely distributed in Northern Europe. According to Lindroth (1992), all north European subpopulations are of relict origin. In our opinion, the discovery of a new subpopulation significantly further north-east from those known by Lindroth, indicates possible existence of ecological refugia in Pinezhye region similar to the canyon-like part of the River Sotka warmed by karst waters. The question of whether the Arkhangelsk Region population is a glacial relict or a result of post-glacial dispersal activity remains open and requires further confirmation, possibly involving DNA diagnostics. However, we hypothesize Pinezhyean subpopulation of $B$. monticola monticola is of a relict glacial origin.

Acknowledgements. The authors are grateful to Kirill V. Makarov (Moscow State Pedagogical University, Russia) for the photograph of $B$. monticola monticola used in this publication as well as for valuable comments on certain finds in the study area. Alexey V. Gornov (Forest Ecology and Productivity Centre Russian Academy of Sciences, Moscow, Russia) is thanked for the habitat photograph. We are indebted to Maxwell V. L. Barclay (Natural His- tory Museum, London, United Kingdom) for proof-reading the manuscript text. Christoffer Fägerström (Lund University Museum of Biology, Sweden) and Ilmar Süda (Estonian University of Life Sciences, Institute of Forestry and Rural Engineering, Tartu) are thanked for providing information on one Latvian locality and the Estonian distribution of the study species, respectively. Vytautas Tamutis (Kaunas T. Ivanauskas Zoological Museum, Kaunas, Lithuania) is thanked for detailed information on the Lithuanian locality and specimen of $B$. monticola monticola. This study, by the first author, was supported by the Russian Science Foundation, project No. 16-14-10031.

\section{References}

Barševskis, A. 1993: The Beetles of Eastern Latvia. Daugavpils, Saule. 221 pp. [In Latvian, English summary.]

Barševskis, A., Bukejs, A. \& Anichtchenko, A. 2008: Faunistic records of the beetles (Hexapoda: Coleoptera) in Latvia. 2. - Acta Biologica Universitatis Daugavpiliensis 8(2): 227-258.

Edemski, M. B. 1926: Preliminary report on geological works in rivers Pinega, Sotka and Kuloe in year 1921, II. - Travaux du Musée Géologique et Minéralogique Pierre le Grand près l'Academie des Sciences de l'URSS 5(5). 9-171 pp. [In Russian.]

Edemski, M. B. 1931: Gypsum of northern areas. With 16 drawings and maps. Moscow, Institute of applied mineralogy. — Tver', State K. Marx typography. 41 pp. [In Russian.]

Filippov, B. Yu. \& Mokhnatkin, A. S. 2008: Ground-beetles (Trachypachidae, Carabidae). — In: Puchnina, L. V., Rykova, S. Yu. \& Rykov, S. M. et al. (eds), Components of ecosystems and biodiversity of karst areas of European North of Russia (on example of Pinezhsky Nature reserve): 251-259. SOLTI, Arkhangelsk. 352 pp. [In Russian.]

Haberman, H. 1968: Eesti jooksiklased (Coleoptera, Carabidae). — Tallinn, Valgus. 598 pp.

Hansen, M. 1996: Catalogue of the Coleoptera of Denmark. - Entomologiske Meddelelser 64: 1-221.

Khromov, S. P. \& Petrosyants, M. A. 2006: Meteorology and climatology: study book. $7^{\text {th }}$ edition. - Moscow State University press "Nauka", Moscow. 582 pp. [In Russian.]

Kryzhanovskij, O. L. 2010: The key to species of Asaphidion and Bembidion occurring in the European part of USSR. - Beetles (Coleoptera) and coleopterists [online]. Zoological Institute, St. Petersburg, Russia. Available from https://www.zin.ru/Animalia/Coleoptera/pdf/kryzhanovsky_script.pdf (updated 1 March 2010; visited 3 September 2017). [In Russian.]

Kryzhanovskij, O. L., Belousov, I. A., Kabak, I. I., Kataev, B. M., Makarov, K. V. \& Shilenkov, V. G. 1995: A Checklist of the ground-beetles of Russia and Adjacent Lands (Coleoptera, Carabidae). - Pensoft Publishers, Sofia-Moscow. 271 pp. 
Lackschewitz, T. \& Mikutowicz, J. 1939: Zur Coleopterenfauna des Ostbaltischen Gebietes. 2. - Korrespondenzblatt des Naturforscher-Vereins zu Riga 63: 4876.

Lindroth, C. H. 1985: The Carabidae (Coleoptera) of Fennoscandia and Denmark. Part I. Fauna Entomologica Scandinavica. Vol. 15. - E. J. Brill/Scandinavian Press Ltd., Copenhagen. 497 pp.

Lindroth, C. H. 1988: Ground beetles (Carabidae) of Fennoscandia: a zoogeographic study. Part II: Maps. Smithsonian Institution and National Science Foundation Washington, Washington. $271 \mathrm{pp}$.

Lindroth, C. H. 1992: Ground beetles (Carabidae) of Fennoscandia. A Zoogeographical Study. Part III. General Analysis with a Discussion on Biogeographic Principles. - Smithsonian Institution Libraries and the National Science Foundation, Washington D. C. 814 pp.

Marggi, W. A., Huber, C., Müller-Motzfeld, G. \& Hartmann, M. 2003: Carabidae: Trechinae, Bembidiini, Bembidiina. - In: Löbl, I. \& Smetana, A. (eds), Catalogue of Palaearctic Coleoptera, Vol. 1: Archostemata - Myxophaga - Adephaga: 241-273. Apollo Books, Stenstrup. 819 pp.

Miländer, G., Monsevičius V. \& Soo, V. 1984: 26 species of Coleoptera new to the Lithuanian SSR, found in 1974-1983. — In: Jonaitis, V. (ed.), New and rare for the Lithuanian SSR insect species. Records and descriptions of 1984: 23-30. Vilnius. 83 pp. [In Russian.]

Müller-Motzfeld, G. (ed.) 2004: Band 2. Adephaga I: Carabidae (Laufkäfer). - In: Freude, H., Harde, K.-W., Lohse, G. A. \& Klausnitzer, B.: Die Käfer Mitteleuropas. Spektrum Akademischer Verlag, Heidelberg. 521 pp.

Netolitzky, F. 1942-1943: Bestimmungstabelle der Bembidion-Arten des paläarktischen Gebietes. - Koleopterologische Rundschau 28: 29-124.

Savich, F. 1998: New data on distribution of rare species of Ground beetles (Coleoptera, Carabidae) in Latvia. Latvijas Entomologs 36: 31-35.

Shalybkov, A. M., Baiderin, V. V., Rykov, A. M. \& Goryachkin, S. V. 1988: Pinezhsky Nature reserve. - In: Sokolov, V. E. \& Syroechkovskiy, E. E. (eds), Nature reserves of the European part of the Russian SFSR.
Part 1: 206-223. Mysl', Moscow. 287 pp. [In Russian.]

Šmits, V. 1968: Materials about Latvian Ground beetles (Carabidae) in the Museum of Zoology of the Latvian State University. - Archives of the Zoological Museum of the Latvian State P. Stučka University 3: 27 36. [In Latvian.]

Solodovnikov, I. A. 2008a: Ground beetles (Coleoptera, Carabidae) of Belarusian Lake Lands (Poozerie). With the catalogue of species of ground beetles of Belarus and the adjacent states: monograph. — Vitebsk, Vitebsk State P. M. Masherov University. 325 pp. [In Russian.]

Solodovnikov, I. A. 2008b: New and rare species of Coleoptera for Belarus and Belarusian Poozerie. - In: Dorofeev, A. M. (ed.), Materials of the $2^{\text {nd }}$ International conference "Biological diversity in Belarusian Poozerie: present status, problems of use and conservation". Vitebsk, 19-21 November 2008. Vitebsk, Vitebsk State P. M. Masherov University: 213-215. [In Russian.]

Solodovnikov, I. A. 2011: Ground beetles (Coleoptera: Carabidae) of Belarusian Poozerie. - In: Dzhus, M. A., Merzhvinski, L. M., Pilovec, G. I., Mikheeva, T. M., Stanovaya, Yu. L., Kolmakov, P. Yu., Yacyna, A. P., Latyshev, S. E., Martynenko, V. P., Shimko, I. I., Kohanskaya, S. P., Piskunov, V. I., Sushko, G. G., Lakotko, A. A., Solodovnikov, I. A., Kuzmich', V. A., Ivanovski, V. V., Kuz'menko, V. V., Kuz'menko, V. Ya., Naumchik, A. V. \& Dorofeev, S. A. (eds), Biological Diversity in Belarusian Poozerie: a monograph: 229-287. Vitebsk, Vitebsk State P. M. Masherov University. 413 pp.

Stiprais, M. A. 1958: New data on Ground beetles fauna of the Latvian SSR. - Archives of the Institute of Biology of the Academy of Sciences of the Latvian SSR 5: 91-110. [In Russian.]

Tamutis, V., Tamute, B. \& Ferenca, R. 2011: A catalogue of Lithuanian beetles (Insecta, Coleoptera). - ZooKeys 121: 1-494.

Venn, S. \& Kankare, M. 2005: Investigating isolation-population biology of Bembidion monticola. - Danish Institute of Agricultural Sciences DIAS Report 114: 269-277. 